\title{
Preface: Special Issue on Emotion, Mood, and Temperament
}

\author{
Nathan Carlin • Donald Capps • Robert Dykstra
}

Published online: 20 May 2014

(C) Springer Science+Business Media New York 2014

The articles in this special issue of the journal are the result of two meetings, both held at Princeton Theological Seminary in Princeton, New Jersey, of the Group for New Directions in Pastoral Theology. These meetings took place in May 2013 and October 2013. Presenters at the conference were invited to write on the topic of Emotion, Mood, and Temperament - the theme for this special issue. Previous papers from meetings of the Group for New Directions in Pastoral Theology also have been published in the journal (see the December 2010, June 2011, August 2012, and October 2013 issues). We are grateful to Lewis Rambo, Editor of Pastoral Psychology, for his ongoing commitment to this group.

It is worth pointing out that over the years the conference format of the Group for New Directions in Pastoral Theology has followed a consistent pattern, which participants have found to be meaningful and helpful. Participants are asked to submit their papers one month before the conference begins so that papers can be read ahead of time. At the conference, which is held over a three-day period, 50 minutes are allotted to the discussion of each paper. For the first 10 minutes of this block, the presenter himself or herself provides a brief overview of the paper. Because all participants have read the paper ahead of time, there is not time set aside for the presenter to read the paper to the group. Then, for a second 10-minute block of time, one designated respondent offers his or her reflections on the paper. In the remaining 30 minutes, the conversation opens to the entire group and then, at the end, the presenter comments on the discussion. Participants have noted, time and again, that they appreciate this structure because it is rare to have sustained discussion about one's own work with colleagues. This kind of public intellectual engagement just does not happen at most other meetings.

It also is worth pointing out that, although most conference participants make an effort to write on the theme, some use this opportunity to present work on a topic that is of current interest to them and for which they seek the feedback of others. Such departures from the theme are welcome because they often stimulate the group's thinking about the next year's theme. Thus, some of the articles presented here are more closely related to the theme than others are, but they all reflect the fact that our conferences provide a wonderful venue for us to learn from one another.

As noted in previous editions of special issues of Pastoral Psychology dedicated to the Group for New Directions in Pastoral Theology, at the end of each conference some time is

N. Carlin $(\bowtie) \cdot$ D. Capps $\cdot$ R. Dykstra

McGovern Center for Humanities and Ethics, The University of Texas Medical School, 6431 Fannin Street JJL 410, Houston, TX 77030, Texas

e-mail: nathan_carlin@yahoo.com 
dedicated to discussing the following year's theme. The discussion that led to the theme of this special issue emerged from the insight that, while theologians in other fields have tended to write about beliefs and behaviors, pastoral theologians have tended to give greater attention to emotions, moods, and temperaments, and that perhaps this creative exaggeration of pastoral theologians is due to the fact that pastoral theologians tend to privilege the subjective experiences of the self over its more objective manifestations. Also, participants noted that most of the attendees have written about human emotions (such as anger, rage, despair, bewilderment, gratitude, joy, and elation), moods (such as depression, sorrow, anxiety, happiness, and longing), and temperament (such as amiability, irritability, irascibility, reliability, and dependability). So, for these meetings, conference participants were encouraged to write papers that focused on an emotion, mood, or temperament that they have written about before or to use this opportunity to explore an emotion, mood, or temperament that is new to them.

As also noted in previous editions of special issues of Pastoral Psychology dedicated to the Group for New Directions in Pastoral Theology, the number of participants is necessarily limited, given the structure of the conference meetings. But given that so many of our colleagues expressed interest in participating in this conference, the Group for New Directions in Pastoral Theology met, as noted, two times in 2013. Thus this special issue of the journal is larger than previous issues. And so we would like to thank Lewis Rambo, again, for the space dedicated this group, which enables us - and readers of this journal - to continue to seek "new directions" in pastoral theology. 